\title{
Single Cell Protein: A Resort to Global Protein Challenge and Waste Management
}

\begin{abstract}
Keywords: Single cell protein; Global; Challenge; Waste management

\section{Abstract}

The increase in human population, death from starvation, civi unrest, malnutrition and related diseases in countries of the world call for serious remedy. Agriculture alone cannot meet with the high demands of protein required worldwide. Single cell protein production, therefore, can be seen as a promising technology in combating this global challenge of food protein shortage. Microorganisms like bacteria, yeast, fungi and algae have been used as sources of single cell protein. Single cell protein not only produces protein, but can also employ the technology of waste management in converting agricultural wastes to food and feed for man and animal consumption.
\end{abstract}

\section{Introduction}

About 50 years ago the less developed areas of the world, Asia, Africa and South America, were the main exporters of grain to the developed world [1]. The food flow though has reversed from the developed world to the less developed since 1948 because of the rate of growth of the world's population especially in the less developed countries $[2,3]$. The continual population growth in the world has necessitated the increase in both animal and human food supply [35].

The increasing world demand for protein rich food led to the search for the formulation of alternative protein sources to supplement the conventional protein sources. Single cell protein (SCP) is one of the most important steps for this goal and it is an alternative and an innovative way to successfully solve the global food problem [4]. In 1996, new sources of protein mainly yeasts, fungi, bacteria and algae named single cell protein (SCP) which was coined to describe the protein production from biomass, originating from different microbial sources [3].

Researches on single cell protein Technology started a century ago when Max Delbruck and his colleagues found out the high value of surplus brewer's yeast as a feeding supplement for animals. During World War I, single cell protein technology proved to be more than useful as Germany used it to replace more than half of its imported protein sources by yeast [6].

Single cell protein is a protein extracted from cultured algae, yeasts, or bacteria and used as a substitute for protein-rich foods, especially in animal feeds or as dietary supplements. Many types of animal feeds contain single cell proteins. It can also be called biomass, bioprotein or microbial protein. The word single cell protein which was coined in the 1960 is considered to be appropriate since most of the microorganisms grow as single or filamentous individuals. Besides its high protein content (about $60-82 \%$ of dry cell weight), single cell protein also contains fats, carbohydrates, nucleic acids,
Journal of

Microbiology \& Microbial Technology

\author{
Kelechi M. Ukaegbu-Obi* \\ Department of Microbiology, College of Natural Science, Michael \\ Okpara University of Agriculture, Abia State, Nigeria \\ *Address for Correspondence: \\ Kelechi M. Ukaegbu-Obi, Department of Microbiology, Col- \\ lege of Natural Science, Michael Okpara University of Agricul- \\ ture, Umudike, PMB 7267 Umuahia, Abia State, Nigeria, Tel: \\ +2348035420868; E-mail: kelechi.ukaegbuobi@yahoo.com \\ Submission: 29 April, 2016 \\ Accepted: 16 June, 2016 \\ Published: 20 June, 2016 \\ Copyright: (c) 2016 Ukaegbu-Obi KM. This is an open access \\ article distributed under the Creative Commons Attribution License, \\ which permits unrestricted use, distribution, and reproduction in any \\ medium, provided the original work is properly cited.
}

vitamins and minerals [7,8].

\section{Waste streams in single cell protein production}

The utilization of waste in the production of single cell protein is an efficient tool for controlling environmental pollution and also essential for cheaper production cost.

Protein of microbial origin, called single cell protein (SINGLE CELL PROTEIN), or microbial protein, can be derived from a variety of micro-organisms, both unicellular and multicellular namely, bacteria, yeasts, fungi, or microscopic algae. The single cell of a microorganism is a perfect protein factory. Under controlled conditions the culture of single cells can effect a highly efficient transformation of agricultural waste such as rice straw, rice hulls, manure, and starchy residues as substrates for growing microbes into protein. If the use of these materials is industrially developed, a vast bulk of them could be rendered economically useful, and this would help control pollution and eliminate some waste-disposal problems as well.

For waste, to be a useful substrate for production of microbial protein, it must meet the following criteria: it should be non-toxic, abundant, totally regenerable, non-exotic, and cheap, and able to support rapid growth and multiplication of the organisms resulting in a biomass of high quality.

\section{Microorganisms Used in Single Cell Proteins}

Algae

Since ancient times, Spirulina was cultivated by people near Lake Chad in Africa and the Aztecs near Lake Texcoco in Mexico. They used it as food after drying it. Spirulina is the most widely used algae. Similarly, biomass obtained from Chlorella and Senedessmus is harvested and used as source of food by tribal communities in certain parts of the world. Algae are used as a food in many different ways and its advantages include simple cultivation, faster growth and rich 
in protein content [9]. The production of algae could be limited by certain conditions such as the need for warm temperatures and plenty of sunlight in addition to carbon dioxide [2]. Another disadvantage associated with using algae as single cell protein is that digestibility is low with algal cells because of indigestible cell walls [10].

\section{Yeasts and fungi}

Many fungal species are used as sources of protein rich food. Among these, most popular are yeast species, Candida, Hansenula, Pitchia, Torulopsis and Saccharomyces. Many other filamentous species are also used as sources of single cell protein. Actinomycetes and filamentous fungi were reported to produce protein from various substrates. Cultures of Fusarium and Rhizopus have been grown in fermentation as a source of protein food. The inoculum of Aspergillus oryzae or Rhizopus arrhizus is selected because of their non-toxic nature. Saprophytic fungi grow on complex organic compounds and convert them into simple structures. High amount of fungal biomass is produced as a result of growth. Mycelial yield vary greatly which depends upon organisms and substrates. There are some species of moulds, for example, Aspergillus niger, Aspergillus fumigatus, Fusarium graminearum which are very dangerous to human, therefore, such fungi must not be used or toxicological evaluations should be done before recommending to use as Single cell protein [11]. Yeasts are probably the most widely accepted and used microorganism for single cell protein [2].

\section{Bacteria}

Among bacterial species, Cellulomas and Alcaligenes are the most frequently used bacterial species as a single cell proteins source [12]. Potential phototrophic bacterial strains are recommended for single cell protein production. Some researchers also suggest use of methanotrophic and other bacterial species for single cell protein production. Generation time of Methylophilus methylotrophus is about 2 hours and this bacterium is used in animal feed; in general produce a more favorable protein composition than yeast or fungi. Therefore the large quantities of single cell protein animal feed can be produced using bacteria [12].

Characteristics that make bacteria suitable for this application include rapid growth of bacteria, short generation times of bacteria - almost can double their cell mass in 20 minutes to 2 hours [13]. They are also capable of growing on a variety of raw materials that range from carbohydrates such as starch and sugars to gaseous and liquid hydrocarbons which include methane and petroleum fractions; to petrochemicals such as methanol and ethanol; nitrogen sources which are useful for bacterial growth include ammonia, ammonium salts, urea, nitrates, and the organic nitrogen in wastes, also it is suggested to add mineral nutrient supplement to the bacterial culture medium to fulfill deficiency of nutrients that may be absent in natural waters in concentrations sufficient to support growth [6].

The use of bacteria is somewhat limited by poor public acceptance of bacteria as food, small size and difficulty of harvesting and high content of nucleic acid on dried weight basis [2].

The selection of certain microbial strain is very important, some of the criteria are:

1. Performance (growth rate, productivity, yield) on specific low-cost substrates to be used Temperature and $\mathrm{pH}$ tolerance

2. Oxygen requirements, heat generation during fermentation and foaming characteristics

3. Growth morphology and genetic stability in the fermentation

4. Ease of recovery, and requirements for further downstream processing

5. Structure and composition of the final product, in terms of protein

\section{Substrates for Single Cell Proteins}

The production of single cell protein can be done by using waste materials and inexpensive feedstock as the substrate, specifically agricultural wastes such as wood shavings, sawdust, corn cobs. Conventional substrates such as starch, molasses, fruit and vegetable wastes have been used for single cell protein production, as well as unconventional ones such as petroleum by-products, natural gas, ethanol, methanol and also human and animal excreta can be used [6]. Lignocellulosic biomass such as cellulose and hemicellulose waste is used as a suitable substrate for increasing single cell protein production $[3,6]$.

In general the more reduced the substrate, the greater the cell yield $(\mathrm{Yx} / \mathrm{s})$ and the more oxygen required for the oxidation of the substrate [14]. British Petroleum developed a technology called proteins-from-oil process for producing single cell protein by yeast fed by waxy n- paraffins, a product produced by oil refineries [15].

These raw materials have been hydrolyzed by physical, chemical and enzymatic methods before [16]. The degree of single cell protein production depends on the type of substrate used and also on media composition [17]. The classical raw materials are substances containing mono and disaccharides, since almost all microorganisms can digest glucose, other hexose and pentose sugars and disaccharides [18].

\section{Requirements for Production of Single Cell Proteins}

Man has been using micro-organisms in the production of food and animal feed for centuries but the single cell protein technology for food was developed over the last 100 years while large scale production was developed in the 20th century and particularly after the First World War.

The process of single cell protein production from any microorganism or substrate would have the following basic requirements and steps:

1. Provision of a carbon source which may need physical and/or chemical pre-treatments.

2. Addition of other nutrients such as nitrogen, phosphorus etc. to support optimal growth of the selected microorganism.

3. A large scale biomass fermenter.

4. Use of sterilization techniques to prevent contamination by maintaining hygienic conditions. The medium components may be heated or sterilized by filtration and fermentation equipments can be sterilized. 
5. The selected microorganism is inoculated in a pure state.

6. Single cell protein processes are highly aerobic (except those using algae) adequate aeration, therefore, must be provided.

7. The microbial biomass is recovered from medium.

8. Processing of the biomass for enhancing its usefulness or storability [19].

\section{Various Applications of Single Cell Proteins}

Single cell proteins have application in animal nutrition as: fattening calves, poultry, pigs and fish breeding.

In the area of food: aroma carriers, vitamin carrier, emulsifying aids and to improve the nutritive value of baked products, in soups, in ready-to-serve meals, in diet recipes.

In the Industries: paper processing, leather processing and as foam stabilizers [3].

\section{Medicinal Uses of Spirulina}

1. Strengthen and improve immune system.

2. Phycocyanins build blood cells.

3. Increase antiviral activity.

4. Exhibits anti cancer activity.

5. Studies showed that Spirulina consumption of 4 weeks reduced serum cholesterol level in human beings by $4.5 \%$ and significantly reduced body weight by $1.4 \pm 0.4 \mathrm{~kg}$ after 4 weeks [20].

6. There is no change in clinical parameters (Blood Pressure) or in biochemical variables (haematocrit, haemoglobin, blood cells, sedimentation rate) and absence of adverse effects.

7. The reduction of cholesterol is partly due to high content of gamma linolenic acid in cyanobacteria.

\section{Single Cell Protein Production Process}

Single cell protein production process takes the following steps

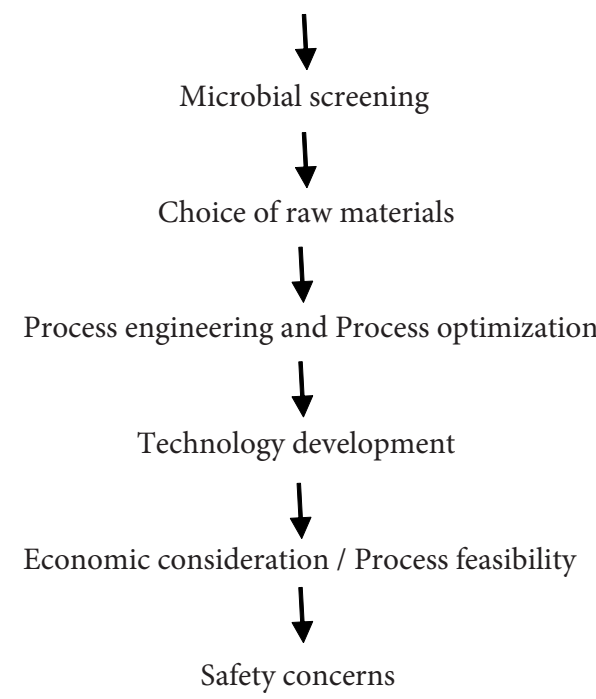

Figure 1: Flowchart of single cell protein production [21].

\section{Microbial screening}

Microbial screening is the first step in production process, suitable microbes which produce good amount of protein need to be selected. Microbial strains are collected from various habitats like soil, water, air and or from other biological materials. Microbes are selected by various studies including mutagenesis and other genetic methods, sometimes wild types are also used [22].

\section{Choice of raw materials}

This part is little cumbersome as there is need to obtain the correct composition of carbon, nitrogen and phosphorus supplements which yield higher biomass production in lesser time. Carbon sources that contain mono- and disaccharides are more desirable since almost microorganisms can utilize them [23].

Substrates for single cell protein production can be subdivided into three categories:

i. High energy sources (natural gas, n-alkanes, gas-oil, methanol, ethanol, acetic acid);

ii. Various wastes (molasses, sulfite waste liquor, milk, whey, fruit wastes); and

iii. Renewable plant resources (sugar, starch, cellulose).

\section{Process engineering and technology development}

The technical conditions of cultivation for the optimized/selected strains are done and all metabolic pathways and cell structures will be determined [19]. Technology development is the next step where the adoption of the technical performance of the process in order to make the production ready for use on the large technical scale.

\section{Economic factors}

Energy consumption, cost of production are the important factor while going for large scale production phase, this need to be thoroughly analyzed and an energy efficient process need to be developed or else it will end up with loss.

\section{Safety demands and environmental protection}

Since the single cell protein produced is for human consumption or for feeding animals safety of the product need to be tested. Certain microbes produce toxic compounds which can have determinable effect on humans and also for the environment, so the whole process should be monitored properly. Safety and the protection of innovation throw up legal and controlled aspects, namely operating licenses, product authorizations for particular applications and the legal protection of new process and strains of microorganisms.

\section{Cultivation methods}

Single cell protein can be produced by fermentation processes, namely:

i. Submerged fermentation

ii. Semisolid fermentation and

iii. Solid state fermentation

Submerged fermentation: In submerged process, the substrate used for fermentation is always in liquid state which contains the 
nutrients needed for growth [24]. Submerged culture fermentations require more capital investment and have high operating cost. The fermentor containing the substrate is operated continuously and the product biomass is continuously harvested from the fermentor by using different techniques. The product is filtered or centrifuged and then dried. High oxygen transfer rate promotes high respiration rate this brings about increase metabolic heat generation during cultivation [19]. This is removed by using a cooling device. The microbial biomass can be harvested by various methods [25]. Single cell organisms like yeast and bacteria are recovered by centrifugation while filamentous fungi are recovered by filtration. It is important to recover as much water as possible prior to final drying which is done under clean and hygienic conditions.

Liquid state fermentation is performed in tanks, which can reach 1,001 to 2,500 square metres $(10,770$ to $26,910 \mathrm{sq} \mathrm{ft}$ ) at an industrial scale. Liquid culture is ideal for the growing of unicellular organisms such as bacteria or yeasts. To achieve liquid aerobic fermentation, it is necessary to constantly supply the microorganism with oxygen, which is generally done via stirring the fermentation media. Accurately managing the synthesis of the desired metabolites requires regulating temperature, soluble oxygen, ionic strength and $\mathrm{pH}$ and control nutrients [26].

Semisolid fermentation: In semisolid fermentation, the substrate is usually used in solid state e.g. cassava waste [27]. The cultivation involves many operations which include stirring and mixing of a multiphase system; transport of oxygen from the gas bubbles through the liquid phase to the microorganisms; and the process of heat transfers from liquid phase to the surroundings [28]. A special bioreactor is designed for identifying mass and energy transportation phenomena, called U-loop fermentor [29]. Production of single cell protein involves basic steps of preparation of suitable medium with suitable carbon source, prevention of the contamination of medium and the fermentor, production of microorganisms with desired properties and separation of synthesized biomass and its processing [30]. Carbon source used can be n-alkenes, gaseous hydrocarbons, methanol and ethanol, renewable sources like carbon oxide molasses, polysaccharides, effluents of breweries and other solid substances [31].

Solid state fermentation: Solid state fermentation (SSF) has been extensively studied with thousands of publications describing various types of bioreactor designs, process conditions and microorganisms for the production of various value added products like single cell protein, feeds, enzymes, ethanol, organic acids, B- complex vitamins, pigments, flavors [32]. This process consists of depositing a solid culture substrate, such as rice or wheat bran, on flatbeds after seeding it with microorganisms; the substrate is then left in a temperaturecontrolled room for several days.

\section{Advantages of Single Cell Protein}

Advantages of using microbes for large scale production of Single cell proteins are

1. Single cell protein high protein and low fat content.

2. Single cell proteins are good source of vitamin.

3. It can be produced throughout the year.
4. Generation times of microbes are less, i.e. they multiply rapidly building up the biomass, more the biomass more the protein source.

5. Protein content is very high in dried biomass up to $85 \%$.

6. During the production of single cell protein biomass, certain microbes produce useful byproducts such as organic acids.

7. Waste (wood waste, food processing waste, hydrocarbons, etc) can be used as a source for carbon for growing microbes there by having advantage of environmental cleanup also.

8. Doesn't require sophisticated lab setup for algae and certain other microbes.

9. High efficiency substrate conversion [6].

\section{Disadvantages of Single Cell Protein}

Even though single cell proteins have the above mentioned advantages, they have some disadvantages also. The major problems associated with the use of single cell proteins are:

1. Many microbes produce various toxic compounds, so consumption of such toxic can have serious effect on health of humans (Food Grade Single Cell Protein), or in animals (Feed).

2. Single cell protein diet supplements can pose allergic reaction.

3. Consuming single Cell Protein, in-taking higher amount of Nucleic acids which can lead to gastrointestinal problems.

4. Food grade single cell protein production is expensive due to the need to maintain high level sterility conditions in the production facility.

\section{Drawbacks of Single Cell Protein Technology}

Although Single cell protein shows very attractive features as nutrients for humans, there are many problems that deter its adoption on global basis. These problems are high concentration of nucleic acids which is $6-10 \%$ which elevates serum uric acid levels and becomes cause of health problems such as kidney stone formation [33]. Another problem is presence of cell wall which is non digestible, in case of algae and yeast, there may be unacceptable color and flavors, cells of organisms must be killed before consumption, there is chance of skin reaction from taking foreign proteins and gastrointestinal reactions may occur resulting in nausea and vomiting [27]. Single cell protein obtained from algae is not suitable for human consumption because they are rich in chlorophyll. Single cell protein obtained from bacteria also has high nucleic acid content, high risk of contamination during the production process and cell recovery also causes many problems.

\section{Current Trends in Single Cell Protein: SPP Single Protein Production}

Creative Biolabs have developed Single Protein Production (SPP) ${ }^{\mathrm{TM}}$ technology for high-throughput protein production.

In the Single Protein Production (SPP) system, live E. coli cells are converted into a bioreactor producing only a single protein of interest in a high yield. A yield of $20-30 \%$ of total cellular protein 
Citation: Kelechi M. Ukaegbu-Obi. Single Cell Protein: A Resort to Global Protein Challenge and Waste Management. J Microbiol Microb Technol 2016;1(1): 5.

ISSN: $2474-4530$

can be obtained with this technology, which overwhelms all protein production methods known so far.

This technology involves the introduction of an mRNA endoribonuclease or interferase in E. coli cells to disrupt the endogenous protein production, however, the cells retain full metabolic activity for RNA and protein synthesis. Therefore, when the mRNA for a protein of interest is engineered to be devoid of the mRNA endoribonuclease recognizing sequence without altering the amino acid sequence of the protein, the cells start to produce any single protein of your choice.

With the evolution of this technology, it is now easy to produce any protein with the SPP system. With the technology, protein yields can be kept unaffected even when the culture is condensed up to 40 -fold and this reduces the cost of protein production by up to $97.5 \%$. The technology provides isotope-labeled proteins at a very high signal-to-noise ratio. More than $90 \%$ of the isotope can be incorporated into the target protein in the SPP system. Furthermore, a refinement of this technology has eliminated lengthy purification steps in the production of membrane proteins suitable for structural studies.

\section{Conclusion}

Single cell protein shows very attractive features as a nutrient supplement for humans and animals alike. Single cell protein has various benefits over animal and plant proteins in that its requirement for growth are neither seasonal nor climatic dependent therefore it can be produced all round the year. Its additional components of carbohydrate, fats and elements like phosphorous and potassium will help solve the challenge in global requirement of protein and other supplements.

\section{References}

1. Brown LR (1968) World food problems. In: Mateles RI, Tannebaum SR (Eds), Single-cell protein. MIT Press Cambridge, USA.

2. Mondal AK, Sengupta S, Bhowal J, Bhattacharya DK (2012) Utilization of fruit wastes in producing single cell protein. Int J Sci Environ Technol 1: 430-438.

3. Nasseri AT, Rasoul-Amini S, Morowvat MH, Ghasemi Y (2011) Single cell protein: production and process. Am J Food Technol 6: 103-116.

4. Najafpur GD (2007) Single cell protein biotechnology advances. Biochem Eng Biotechnol Adv 332-341.

5. Tesfaw A, Assefa F (2014) Co-culture: a great promising method in single cell protein production. Biotechnol Mol Biol Rev 9: 12-20.

6. Suman G, Nupur M, Anuradha S, Pradeep B (2015) Single cell protein production: a review. Int J Curr Microbiol Appl Sci 4: 251-262.

7. Asad MJ, Asghar M, Yaqub M, Shahzad K (2000) Production of single cell protein from delignified corn cob by Arachniotus species. Pak J Agri Sci 37: 3-4.

8. Jamel P, Alam MZ, Salleh NU (2008) Medai optimization for bioproteins production from cheaper carbon source. J Eng Sci Technol 3: 124-130.

9. Arora DK, Mukerji KG, Marth EH (1991) Single cell protein from molds and higher fungi. In: Hand book of applied mycology: foods and feeds, vol. 3 Banaras Hindu University, Varanasi, India, pp. 499-539.

10. Ware SA (1977) Single cell protein and other food recovery technologies from wastes. Municipal environmental research laboratory office of research and development, U.S. environmental protection agency, Cincinnati, Ohio 45268, USA.
11. Weitzel W, Winchel M (1932) The yeast its nutritive and therapeutic value. Verlag Rothgiese und Diesing, Berlin, Germany.

12. Bhalla TC, Sharma NN, Sharma M, Gunasekaran P (2007) Production of metabolites, industrial enzymes, amino acids, organic acids, antibiotics, vitamins and single cell proteins. National Science Digital Library, India.

13. Bamberg JH (2000) British petroleum and global oil 1950-1975: the challenge of nationalism. Cambridge University Press, Cambridge 6: 445-478.

14. Mateles RI (1979) The physiology of single cell protein production. Soc Gen Microbiol Symp 29: 29-52

15. Ageitos JM, Vallejo JA, Veiga-Crespo P, Villa TG (2011) Oily yeasts as oleaginous cell factories. Appl Microbiol Biotechnol 90: 1219-1227.

16. Zubi W (2005) Production of single cell protein from base hydrolyzed of date extract byproduct by the fungus Fusarium graminearum. MSc Thesis, Garyounis University, Benghazi, Libya 19: 167-225.

17. Mondal AK (2006) Production of single cell protein from fruits waste by using Saccharomyces cerevisiae. Am J Food Technol 58: 117-134.

18. Richmond A (2004) Handbook of microalgal culture: biotechnology and applied phycology, Blackwell Science, Australia 6: 87-124.

19. Srividya AR, Vishnuvarthan VJ, Murugappan M, Dahake PG (2014) Single cell protein- a review. Int J Pharm Res Scholars 2: 472-485.

20. Becker EW (2007) Micro-algae as a source of protein. Biotechnol Adv 25: 207-210.

21. Wijeyaratne SC, Jayathilake AN (2000) Characteristics of two yeast strains (Candida tropicalis) isolated from Caryota urens (Kithul) toddy for single cell protein production. J Natl Sci Found Sri Lanka 28: 79-86.

22. Kuhad RC, Singh A, Tripathi KK, Saxena RK, Eriksson KE (1997) Microorganisms as an alternative source of protein. Nutr Rev 55: 65-75.

23. Nigam JN (2000) Cultivation of Candida langeronii in sugarcane bagasse hemicellulosic hydrolyzate for the production of single cell protein. World $J$ Microbiol Biotechnol 16: 367-372.

24. Varavinit S, Srithongkum P, De-Eknamkul C, Assavanig A, Charoensir K (1996) Production of single cell protein from cassava starch in air-lift fermenter by Cephalosporium eichhorniae. Starke 48: 379-382.

25. Kargi F, Shuler ML, Vashon R, Seeley Jr. HW, Henry A, et al. (1980) Continuous aerobic conversion of poultry waste into single-cell protein using a single reactor: kinetic analysis and determination of optimal conditions. Biotechnol Bioeng 22: 1567-1600.

26. Capalbo DM, Valicente FH, Moraes IO, Pelizer LH (2001) Solid-state fermentation of Bacillus thuringiensis tolworthi to control fall armyworm in maize. Electron J Biotechnol 4: 1-4.

27. Adedayo MR, Ajiboye EA, Akintunde JK, Odaibo A (2011) Single cell proteins: as nutritional enhancer. Adv Appl Sci Res 2: 396-409.

28. Andersen BR, Jorgensen JB, Jorgensen SB (2005) U-loop reactor modelling for optimization. Part 1: estimation of heat loss. J Environ Issues 9: 88-90.

29. Oscar AP, Jorgensen JB, Jorgensen SB (2010) Systematic model analysis for single cell protein (SCP) production in a U-loop reactor. 20th European Symposium on Computer Aided Process Engineering - ESCAPE 20.

30. Soland $L$ (2005) Characterization of liquid mixing and dispersion in a U-loop fermentor. Am Eur J Agric Environ Sci 67: 99-109.

31. Talebnia F (2008) Ethanol production from cellulosic biomass by encapsulated Saccharomyces cerevisiae. PhD Thesis, Chalmers University of technology, Gotheburg, Sweden 334: 113-145

32. Singhania RR, Patel AK, Soccol CR, Pandey A (2009) Recent advances in solid-state fermentation. Biochem Eng J 44: 13-18

33. Bankra AV, Kumar AR, Zinjarde SS (2009) Environmental and industrial applications of Yarrowia lipolytica. Appl Microbiol Biotechnol 84: 847-865. 